\title{
Research on the Training Mode of Marketing Major in Industry Characteristic Colleges under the Background of Big Data
}

\author{
Ling Guo ${ }^{1, a}$, Youqin $\mathrm{Wu}^{2, \mathrm{~b}}$ and Jinping $\operatorname{Tan}^{3, \mathrm{c}}$ \\ ${ }^{1}$ The Department of Law and Business of College of Technology and Art Jingdezhen Ceramic \\ Institute, China \\ ${ }^{2}$ The Department of Law and Business of College of Technology and Art Jingdezhen Ceramic \\ Institute, China \\ ${ }^{3}$ College of Technology and Art Jingdezhen Ceramic Institute, China \\ a33837770@qq.com, b04909155@qq.com, ${ }^{c}$ 1904524874@qq.com
}

Keywords: Big data; Industry characteristic; Marketing major; Training mode

\begin{abstract}
Big data has a great impact on education and teaching in Colleges and universities, and promotes the development of education and teaching in Colleges and universities in the direction of information and digitalization. Taking the marketing major of College of Technology and Art Jingdezhen Ceramic Institute as the research object, taking the marketing major of Jingdezhen ceramic University of science and technology as an example, using the methods of investigation and literature research, this paper actively explores and innovate the training mode of marketing professionals from the aspects of professional training target, curriculum system construction, teaching method reform, teacher team construction and so on.
\end{abstract}

\section{Challenges Brought about By the Age of Big Data to the Training of Marketing Professionals}

The concept of "big data" was first proposed by the US McKinsey Co in 2011 and became popular in China in 2012. From a broad perspective, big data is a collection of methods, tools and tools to collect, organize and analyze large data sets.[1] At present, with the development of information technology, especially the rise of network e-commerce, as well as the establishment of network social platforms such as micro-blog, WeChat, QQ, the global data presents an explosive growth, the digital process of each industry is accelerating, and the data has penetrated into all walks of life. The rapid development of Internet information technology has made changes in marketing channels and patterns, Big data, traffic dividends, fans economy and other large Internet vocabulary flooded the market.[2] In the context of big data, market analysis and precise positioning with big data technology have become an important part of marketing activities. [3] Business schools in many well-known colleges and universities have opened new courses and disciplines related to big data. For example, in the United States, a new subject of computational advertising has been set up in the United States. In the background of large data, how to introduce big data thinking and value system into the teaching of marketing major in higher education, and promote the innovation of marketing professional education thought, method and theory, so that the marketing professionals can better adapt to the demand of the market in the background of the big data age, which is of great practical significance.

\section{The Current Situation of Marketing Professionals Training In Chinese Industry Characteristic Universities}

The industry characteristic university is the product of the specific historical period of the development of higher education in China. Industry characteristic colleges and universities refer to universities or colleges that rely on the industry and focus on the needs of the industry, aiming at the characteristics of the industry, and cultivating high-quality professionals for specific industries. [4] These colleges and universities continue to expand the service orientation around the original industry demand, and highlight the industry characteristics. At present, the widely recognized model 
of marketing personnel training in the world is: the CBE model represented by the United States, the "dual system" model represented by Germany, the CBET model represented by the UK and Australia, and the "unit" model represented by Japan. On the basis of the experience of foreign cooperative education, the training of marketing professionals in China's colleges and universities has also carried out a variety of innovations. In the form of training, there are several forms of training, such as " Alternation of work and study ", "2+1" and "order", and some practice has also achieved certain achievements. [5] But through the survey, we find that there are still some problems such as disjointing the target of talent training with the market demand, the lack of professional characteristics, the unreasonable course system, the single teaching method, the lack of practical training base and the lack of practical platform, which can not well satisfy the needs of marketing professionals in the context of big data.

The College of Technology and Art Jingdezhen Ceramic Institute is a higher institution with obvious industry characteristics. It has the advantages of ceramic industry. In the background of rapid development of Internet information technology and economic globalization, in order to cultivate better marketing talents, the College of Technology and Art Jingdezhen Ceramic Institute has carried on the reform and exploration to the training mode of marketing major.

\section{Training Mode of Marketing Professionals with Industry Characteristics in Big Data Era}

Accurately positioning, highlighting characteristics, and establishing a professional education concept with ability training as the core. In the background of large data, the society puts forward higher requirements for the knowledge structure, creative ability and comprehensive literacy of the marketing talents. On the basis of the in-depth analysis of the demand for applied marketing professionals at the present stage of social development, colleges and universities should make clear the training objectives of the marketing major in the colleges and universities. Taking the marketing major of the College of Technology and Art Jingdezhen Ceramic Institute as an example, the school further clarifies the training goal on the basis of extensive investigation: to cultivate the advanced applied marketing talents of "wide caliber, thick foundation, strong ability and heavy quality", which are rich in innovative spirit and practical ability, and serve the development of local economy. In order to better adapt to the social development, relying on the advantage resources, it has established the core of application ability, training to promote the employment of students and focus on the professional characteristics of the ceramic industry.

Establishing a two-way driven application oriented training mechanism, and scientifically formulating a talent training plan. The so-called two-way driven refers to employment driven and market driven. Employment driven is based on the employability of college students, designing corresponding professional teaching modes and teaching plans around employment skills, emphasizing the promotion of employability. Market driven refers to the pillar industry based on the local economy or the industry with larger market demand. It adjusts and designs the professional teaching mode and teaching plan around the market demand, emphasizing the cultivation of industry skills. The College of Technology and Art Jingdezhen Ceramic Institute is guided by the market orientation and employment orientation. On the basis of understanding the requirements of the ability and quality of the marketing personnel, starting from the development potential of the students' employment and the development potential of the students, the training mode of " marketing major centered on the cultivation of professional application ability" is constantly explored, as shown in Fig. 1. The training mode of "theory education, discipline foundation, professional competence and professional quality" has been formed. 


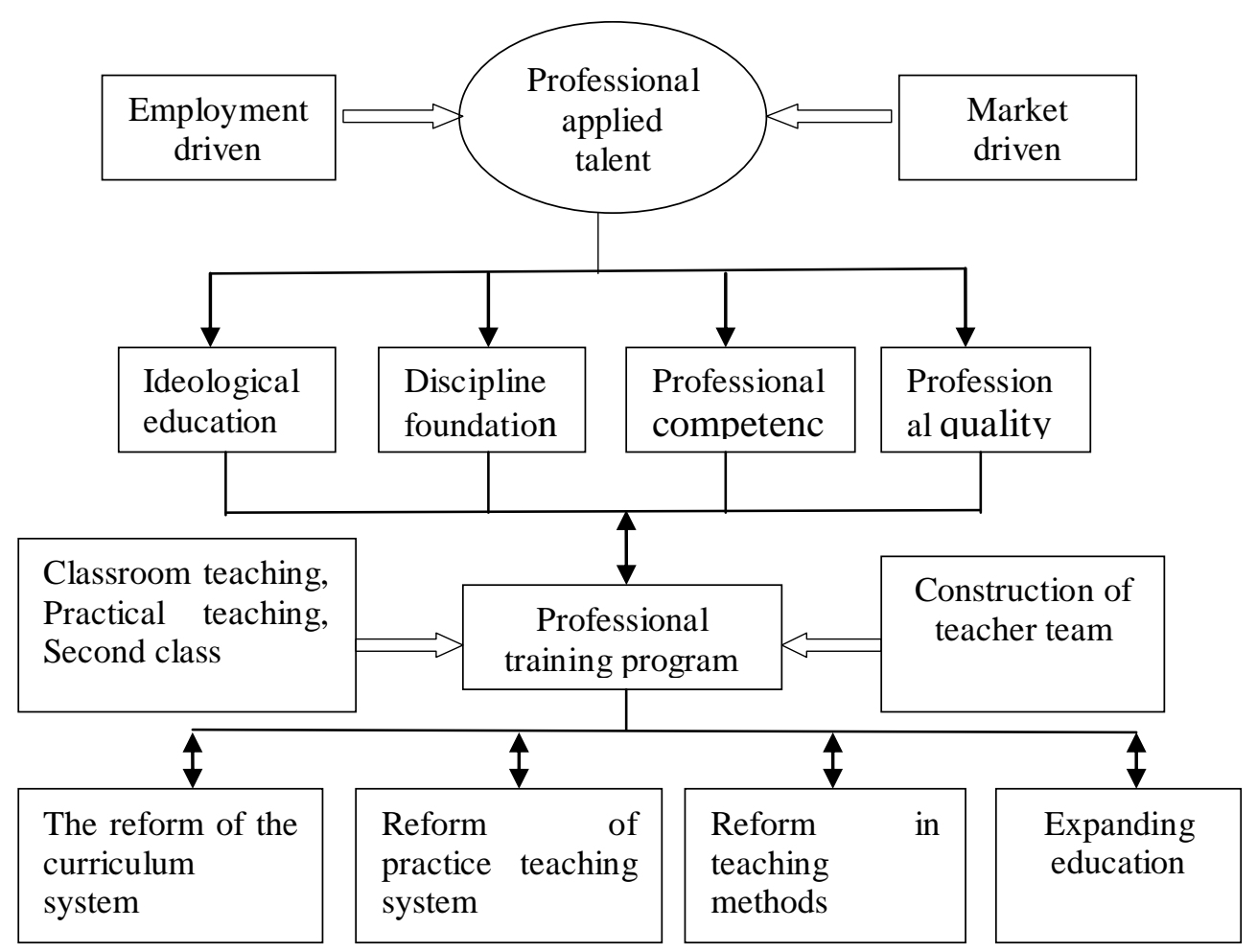

Figure 1. The training mechanism of marketing professionals

Optimizing the curriculum system and highlighting the characteristics of industry marketing. The construction of the subject system should reflect the characteristics of the industry. Relying on big data, according to the needs of social development and the demand of the big data era, we should build an integrated knowledge structure of knowledge crossing, infiltration and integration. The marketing professional course system of College of Technology and Art Jingdezhen Ceramic Institute emphasizes "wide caliber, thick foundation, strong ability and high quality". It has formed the general curriculum of "emphasis on basic knowledge", the professional curriculum system of "strengthening professional ability" and the development curriculum system of "focusing on professionalism". In the course of planning course content and course system, based on the characteristics of ceramic industry, it set up the elective course of ceramic industry and the practice course of ceramic art. In the 2014 edition, the college set up the curriculum of "ceramic appreciation and production", which was compatible with the needs of the ceramic industry. At the same time, using the superior resources of the college in the ceramic industry, students are encouraged to actively participate in the lectures offered by domestic and foreign scholars to ceramics and so on, so that students have a certain understanding of the ceramic industry and ceramic products.

Strengthening practice teaching to enhance students' application ability. In the process of planning practical curriculum content and curriculum system, we should firmly grasp the development trend of marketing major. According to the new development and new requirements of research and industry in the marketing industry at home and abroad, we will further determine the requirements of marketing professional ability and quality, and achieve the goal of ability training through different courses in the course system. In the training of marketing major in College of Technology and Art Jingdezhen Ceramic Institute, the four year practice of university is continuous, the first grade is based on basic experiment, grade two and grade three are mainly designed and professional experiment, and the four grade is based on comprehensive experiment and research experiment. At the same time, the college actively cooperates with enterprises, strengthen the construction of practical teaching base, sign the practice agreement with Jingdezhen sunset red ceramic cultural and creative company and so on. It has set up a practice teaching system which combines class with extracurricular, theory and practice, four years of continuous line, centralized and decentralized, which further strengthens the cultivation of students' application ability. 
Actively carrying out reform of teaching methods and innovating teaching methods. In the process of teaching, teachers can try various teaching methods to arouse students' enthusiasm for learning, so that students can change from "want me to learn" to "I want to learn". We can use case analysis, role playing and classroom debate to make students change their role from passive listening to active thinking, analysis and participation, which can not only deepen the students' theoretical grasp of professional knowledge, but also train students' ability of thinking, data collection and expression. In addition, with the support of large data, more and more teaching resources appear in the form of electronic data. The reform of teaching methods in Colleges and universities should follow the pace of the development of the times, and change from the past classroom teaching to the cooperative development of classroom teaching and extracurricular network education.[6] Outside the classroom, students can use mobile terminals to develop autonomous learning and interact with teachers. Under the background of large data, relying on the mass of teaching materials and curriculum resources, the quality of network teaching resources can be improved and the teaching resources can be optimized and widely accepted.

Building "double quality" teaching staff oriented with the guidance of Applied Ability Cultivation. Teachers are important safeguard measures to improve teaching quality. In the construction of teachers' team, colleges and universities should be based on the characteristics of marketing specialty. In addition to paying attention to the basic theory and scientific research ability of teachers, they should also take professional background and practical experience as the important content of selecting and recruiting teachers and training teachers. When recruiting teachers, teachers tend to have both professional education background and marketing experience. In the field of teacher training, the teachers' educational and teaching ideas are innovating. The teachers should effectively recognize the characteristics and trends of the development of large data, promote the teaching work by relying on large data technology, collect the latest information of various disciplines through network channels, effectively grasp the forward moving direction of the development of the subject, and carry out the teaching interaction in an orderly way. At the same time, universities should support teachers' participation in school enterprise cooperation research, encourage teachers to conduct horizontal research, and encourage teachers to do business research or job training.

\section{Reference}

[1] L.Y.Cui. Reflections on statistics education based on the background of big data Era(MS. Capital University of Economics and Business,China 2014),P.2.(In Chinese)

[2] X.Zhang: Market Modernization, Vol(2017)No.12,p.79. (In Chinese)

[3] C.S.Cao: New communication in China,Vol(2018)No.6,p.239. (In Chinese)

[4] X.Y.Sun, W.Ch.Wang and G.Deng: Education and Profession, Vol (2018) No.9, p.49-50. (In Chinese)

[5] X.H.Li. FZ Career Academy marketing professionals training mode innovation research (MS. Kunming University of Science and Technology,China 2013),P.15-17.(In Chinese)

[6] Y.X.Liang: Heilongjiang Science,Vol.9(2018)No.11,p.96-97.(In Chinese) 